\author{
Dalia Šiukštiené ${ }^{*}$ \\ General Jonas Žemaitis Military Academy of Lithuania
}

\title{
China: Rational Expectations and Economic Nationalism
}

\begin{abstract}
China's transformation from the world's economic periphery into its nucleus has been labelled as an example of either the horror of globalization, or of its success. The enormous growth pace of the Chinese economic and political potential had become an important challenge to the status quo of the international system. The author of the article, having employed the basic statements of the political economy and official statistical data as well as institutional assessments, is developing the idea that China's comeback to the world's dynamic economy after a number of decades of autonomy has been determined by the ability of the country's political and business elite to choose priorities so as to liberate the market forces, use the surplus of the world capital and its regular movement to the places where marginal profit is the highest, and, at the same time, expediently manipulate the Sino-centric attitudes of the nation. However, it starts to be obvious that the national bureaucracy that is prone to yielding to the dictatorship of the defensive economic nationalism and is striving at unproportionally high benefits for itself may lose the main stimulant of the economic growth, i.e. foreign investment.
\end{abstract}

\section{Introduction}

"It is due to China that goods in European shops are cheaper, business costs are lower, European companies are more competitive, markets are larger for European exporters and interests are lower", happily said Mr. Peter Mandelson, the European Commission member responsible for trade when he was presenting the new document of EC - China strategic relationship on October 24, 2006. ${ }^{1}$ His report included statements that Europe is interested in supporting China in both political and economic terms, so that it could successfully become a prosperous, stable and open country where the guiding principles are those of the state of justice and free market. A few years ago, Mr. Supachai Panitchpakdi, Director General of the WTO, said that China was the only economic example in history that could be named as the engine of the world economy and that China itself was the source of inspiration for other developing states ${ }^{2}$.

\footnotetext{
" Dalia Šiukštiene - economist, lecturer of Department of Political Science at the Military Academy of Lithuania. Address: Šilo 5A, LT-10322 Vilnius, tel. +370 5 2103569, e-mail: d.siukstiene@delfi.lt

1 IP/06/1454, http://ec.europa.eu/trade/issues/bilateral/countries/china/index en.htm, 06022008.

2 Supachai Panitchpakdi, "Putting the Doha Development Agenda back on track: why it matters to China", Speech at the International Forum "WTO and China", Beijing, 10 November 2003.
} 
After the historic stagnation of the mid-seventies, when China's share of the world's GDP was down to merely 8 percent, China's economy is again "coming on stage". According to data shown in 2007, it is the fourth in the world after the US, Japan and Germany. To paraphrase the idea of Mr. Jean-Claude Trichet, President of the Bank of Europe, it demonstrates a rebirth of China's power in reference to the fact that back in 1820, China and India together were producing about one half of the world's output ${ }^{3}$.

However, China has often been nicknamed "a ravenous dragon" in the press during 2008. It has been accused of instigating a new wave of colonialism and of trying to leave the developed countries high and dry. While China's unstinting appetite for commodities is super, the International Energy Agency expects China's imports of oil to triple by 2030 creating such a bonanza for farmers, miners, oilmen and bankers that economic novelty phrases like "bull market", "cyclical expansion" or "supercycle"t have become a part of their daily vocabulary.

As China's dependence on non-renewable sources of energy increases together with its world leadership in the consumption of coal, steel and copper, with its needs for oil and electric power being only second after those of the USA, the leaders of industrial countries, including political leadership of China itself, become increasingly worried. A steep turn of the industrial structure towards basic industry means an even bigger need for natural recourses and more dramatic consequences for the people of the world. The fact that China's metallurgy consumes over 16 percent of all the country's energy (the basis of which is the burning of coal) and all the households in the country consume only 10 percent of it ${ }^{5}$ gives rise to fears of more acid clouds in the atmosphere and permanent smog for Chinese cities inhabitants. With the blessing of the government, the Chinese banks pay very low interest to their depositors and provide "cheap" loans to state enterprises. While the latter pay only symbolic land taxes and dividends, they are able to allocate more profit to industrial development and expansion of new production, which however is as energyintensive and environment-polluting as ever. It means in fact, that the citizens of modern China - bank depositors and tax payers - subsidize their country's basic industry, which unfortunately is slowly but successfully poisoning themselves.

It would be unfair not to notice amidst all the problems and threats, the ability of the country's political and business elite to choose priorities so as to liberate the market forces and use all the possibilities that can be provided by trade, foreign investment and technological imports to those who seek speedy economic and industrial growth in state and private sectors. In other words, the political and economic phenomenon of China has proven that lagging behind implies certain benefits and the market newcomers may gain a lot by applying aggressive and "incorrect" tactics.

\footnotetext{
3 Information of the World Bank (see: www.worldbank.org, 1203 2008).

4 "The new colonialists", The Economist, March 15 ${ }^{\text {th }}$ 2008, p. 13.

5 Ibid.
} 
The format of the article does not allow one to embrace all the aspects and changes of the phenomenon within the international economic environment and its relationship with major players of the global system - the USA, EU or Russia that are being provoked by the growing power of China. Thus, the author restricts herself to the assumption that the macro-economic policy of the People's Republic of China is the main arena the witnesses his political competition as well as strives at its major goal - to verify the projections of the XX-th century in our modern context (2008). Having experienced that most modern analysts seemingly get stuck in the level of theoretical options and go too deep into national self-respect by scrutinizing the reflections of sustainability of power balance and geo-political changes within the Chinese economic strategy, the author's use of theoretical thoughts is sporadic and based on the information provided by The Economist (2008), which promotes the philosophy of the free market economy, as well as on the data of surveys of international business organizations and statistics. The interpretation of modern facts is presented in three complementary chapters in search of a correlation with two modern theoretical approaches. The first one - the aspect of rational expectations, the importance of which for economics has been acknowledged since Keynes used the notion of "real vitality" in his "General Theory" while explaining the fluctuations in investments. The second approach is the economic nationalism ${ }^{7}$ that emerges due to the market's feature of accumulating wealth and creating power relationship among the countries of different economic strength. Such an approach of the analysis allows for the identifying of two new opportunities for the development of the Chinese economy as well as two threats that may become obstacles in realizing the vision of the country as "the first among the equal". The opportunities of the "new generation" lie in the utilization of the infrastructure factor as a possible economic multiplier, the "employment" of the world financial capital surplus in the area and in the stimulation of the Sinocentric attitudes of the nation promoting the increase of labour added value. The first threat is the inert bureaucracy at the national level and its strive to be above the regional bureaucrats manifest in the decisions of defensive economic nationalism by nature. The second one is the rising level of the communist and Maoist ideological heritage in internal politics and ideology, which induces anti-Western nationalism and existence of double standards in the minds of a billion-strong nation that is encouraged by the inspirations of a harmonious society but frustrated by social exclusion.

\footnotetext{
${ }^{6}$ Blanchard, Oliver, Macroeconomics, New Jersey: Pearson Education, Inc., 2006, p.387.

7 Economic nationalism creates economic rent that goes to interest groups; in other words, economic wellbeing of the society is sacrificed for the interests of separate groups - it is the deal between the state and the producers. The most earnest advocates of the economic nationalism in all countries have always been the national bureaucrats and local producers representing the interests of their promoted areas of production (see: Rostow, W.W. Politics and the Stages of Growth, New York: Cambridge University Press, 1971, p.189).
} 


\section{The Philosophy of Peaceful Rising and the Cognitive Dissonance in Modern Chinese Ideology}

While little is known about the origin of and reasons for technological and other types of innovations, often it is being explained on the academic level that innovations have a strong tendency for accumulation with respect to time and location. Allegedly, they turn up at a certain time in the economies of certain countries. It depends only on relative effectiveness and relative advantage for the innovation centres to emerge or decline. It was Leon Trotsky who, in his research on the late stage of Russian industrialization, wrote about "the law of combined and uneven development", when the states are destined to achieve best results in their technological advances if they promote the imports of foreign technologies and are able to accommodate these technologies with the traditional social models ${ }^{8}$. The structural changes in the world economy of the end of the XX-th century have effectively destroyed the propositions of the political economy in less-developed states being unable to progress in an unreformed system of the world capitalism. China's example forced authors on political economy subjects to distance themselves from the statements so popular a few decades ago, that in the world of national states and political borders it was impossible to avoid conflicts when developing states or separate economy sectors tried to overcome existing barriers. Recently, another thought is more popular, which affirms that the Chinese nation has realized a long while ago how "a well-organized hierarchic state" should exist, and its strive to re-establish the principle of fairness provokes its goal to regain the former regional power, and thus stimulates relevant actions ${ }^{9}$.

\subsection{New Strategy - To be "the First among the Equals"}

One should recall that the path of autonomic development based on socialistic reforms was chosen by several countries 5 decades ago. They declared their willingness to participate as little as possible in what they called the capitalist economy of the hostile imperial world. Some advocates of the dependency theory also were proposing that way and supporting the choice of those states at a theoretical level. Some of the states - Cuba, Tanzania and China - have really achieved certain strategic goals of well-being and economic fairness.

However, as Chinese economic analysts say, the anticipated results in

\footnotetext{
8 Knei-Paz, Baruch, The Social and Political Thought of Leon Trotsky, Oxford: Clarendon Press, 1978, p. 89.

9 Castro, R., "Exploring the Prospect of China's Peaceful Emergence in East Asia", Asian Affairs: An American Review, Vol. 33 Issue 2, 2006, p. 86.
} 
the social and economic sectors have not been in place for too long ${ }^{10}$, and Mao Zedung's program of "the Great Leap Forward" (1958 - 1961) collapsed when they distanced themselves from the Soviet Union. The rise of the Cultural Revolution destroyed the country's scientific-technical base even further bringing down the entire economy. Decades were needed before Deng Xiaoping, who took over right after Mao's death, started talking about the fact that no nation is able to develop "behind closed doors", as it was isolation that brought China to poverty, backwardness and ignorance ${ }^{11}$.

When attempts are made at the academic level to determine modern China's place in the world system, its geo-political identity and foreign policy are often explained by the philosophy of regaining "the right place in the world" and by traditional Confucianism values - pride in their history, achievements of civilization, striving for universal and all-embracing harmony. Even Lithuanian political analysts pay attention to the frustration about the fact that China still is not the first country in the world when they discuss the propositions of the Chinese geopolitical identity researchers that ethnocentric rise of their state is a self-explanatory issue ${ }^{12}$.

"The peaceful rising" concept of the Chinese foreign policy that came into being at the time of the so-called fourth generation of leaders, reflects the modern imperialistic ideology of China. According to different sources, this type of ideology is based on the objective of economic, military, social and cultural cooperation among the neighbouring states which should be mutually beneficial. That is why the role of China, or "Middle state" as Chinese themselves call it (Zhongguo in Chinese), in cooperation is not to control unambiguously but to be the state that is "the first among the equals".

Analysts believe that the feeling of "historic injustice" that is deeply imbedded in the Chinese nation provokes expectations for the lost regional power $^{13}$. The main power of realization of such expectations is the permanent stimulation of a society's dissatisfaction about the existing economic achievements. All social and economic tendencies can be assessed with the help of conceptual mathematical propositions, which makes it appropriate to employ the law of big numbers with respect to the Chinese economy and place any set of events into a clear chain. Thus, by way of careful interpretation and use of 1 percent of 1.3 billion as an example, we can hypothetically assess the potential and influence of the expectations for "historic injustice correction" not only

\footnotetext{
${ }^{10}$ Rydenfelt, Sven, A Pattern for Failure: Socialist Economies in Crisis, San Diego: Harcourt Brace Jovanovich, 1985, p. 204-213.

${ }^{11}$ Ibid.

${ }^{12}$ Lopata R., Statkus N., "Empires, the World Order and Small States", Lithuanian Annual Strategic review 2005 , p. 47

${ }^{13}$ According to some sources, the Chinese assess the rise of their country as realization of justice - a selfexplanatory matter in gaining the once-lost status. The nation takes pride in its historic and civilization achievements and naturally accepts the process of regaining China's power - as if it was historically determined, and at the same time they express disappointment in the present situation [see: Lopata, (note 12)].
} 
for the development of China, but for the world system as a whole. Although the history of economy presents examples as to when people, companies or financial markets stakeholders, having lost the sense of reality, used to become overoptimistic or over pessimistic and their expectations were doomed, all known cases were related to technical-informational limitations. Modern communication technologies, e.g. the Internet, can provide unlimited possibilities for strengthening of individual bilateral relations and increase the possibilities for realization of those expectations.

Political forces in China demonstrate really smart manipulation with the Sino-centric attitudes of the nation and its traditional values in forming the zone of economic, political, and cultural-civilization influence. Five years ago, the Chinese were encouraged to be proud of their first space mission and its achievements that would help them catch up with the USA and Russia; in 2007 - that their compatriots were ready for a mission to the Moon; and in 2008 - that they managed to organize the most lavish Olympic Games in history with unlimited budget and proved to the world that they were not only the largest but also the most sportive nation. For once, they managed to overcome the USA when the Chinese Olympic team received 100 Olympic awards and the largest number of gold medals, and the gold medallists were awarded by the government with the largest financial rewards -1 million USD each.

China had always had many advantages of a strong state, lots of economic resources and a comparatively large local market however, it had not been able to fulfil the strategy of autonomous development. Obviously, after several decades of autonomy China has been able to come back to a dynamically developing global economy only with the help of the economic achievements of other countries - Western investment, modern technologies and free trade. Still, it is also obvious that China's economic revival campaign has been based on the slogan impact that was enforced in the Mao era and can be explained by the cognitive dissonance ${ }^{14}$.

\subsection{Mao's Image - An Instrument for Strengthening the Power of the State}

According to those analyzing the China case, there was a single personality in its history, the Emperor Qin Shi Huang, who started to erect the Great Chinese Wall by his popularity and influence on the decisions of a billion-strong nation he was comparable to the influence of Mao who died in 1976. Although the former leader's ideological heritage impact on economic development is considered symbolic, Mao's portraits on Chinese banknotes, travel bags and shopping baskets, brooches and pins, watches and other items on sale is

\footnotetext{
${ }^{14}$ The campaign slogan "Truth from facts" can be equaled to a Mao slogan "Serve the People", because both create a sincere public cognition of certain things and trust in them, although something different is being done within the country (see: "Staying at the top", The Economist, December 22 $2^{\text {nd }}, 2007$, p.116).
} 
emphatically important. The importance of innovation is being continuously reminded by Mao portraits and his slogans to the working and creative people of China ("Let a hundred flowers bloom"), together with permanent competition ("Fear no sacrifice") and relentless self-criticism. As the researchers of the Mao phenomenon declare, he was able to avoid rallies and other events where he could have been criticized, and he used to make public speeches only when he had new plans and a vision for the future. It is common to assess the economic achievements of China of those days as shabby, its economic policy as having no "carcass" and its leadership as "brainless"; however, every initiative or a declared innovation seemed to turn into a new centripetal force for the strengthening of the power of the state. The science of management would call this type of influence the impact of restructuring - the broader you disperse the actions and functions, the easier you can hide from responsibility, or if you can't do anything right, do a lot (the broader the better).

The Chinese economy started to recover after the end of the Mao era and with the introduction of the botched economic policies, and many other positive achievements, which are related to the name of Deng Xiaoping. The rhetoric of this leader of the country helped create the program of the four modernizations and draw the world's attention to the modern socially-focused market economy and the defence system to match the status of a super-state; however, his portrait is not to be seen even on a low-value coin. Mao's power is manifest in the unity of thousands of people in the critical situation of the aftermath of the earthquake of May 12, 2008 in the South-West Chinese province of Sichuan, when the so-called "middle-class" representatives organized an "express train" made up of their private cars and taxis to drive the victims. The world press sarcastically commented later on that the Chinese Prime Minister, Wen Jiabao had "to hurry up in order not to be late for the stage and play a sobbing head of the salvage operations for five days" 15 .

It was believed that the leaders of the Chinese economic policies will seek to preserve the impact of the Mao image, easily explainable by the cognitive dissonance, for as long as possible in order to manage the minds and work results of a billion people. That would mean successful manipulation by modern instruments of image support, which proved to be so powerful in China. The management science experts would label these instruments as popularizing of the resonant slogans, support for the "spicy" press image, promotion of the circle of the devoted congenial friends and exploitation of the human passion for the creation of plans and visions. As the famous novelist and poet Edgar Allen Poe noted, human life is full of happiness primarily because a man is continuously waiting to become happy soon.

15 “China helps itself", The Economist, May 24th 2008, p.68. 


\section{The Spirit of the Four Modernizations}

The history of the global economic growth and structural changes is an interlacing pattern of the periods of active liberalism, openness and free economy with the stages of stagnation, protectionism and national conflicts. Structural changes within countries provoke economic conflicts; consequently, on a theoretical level there is a tendency to be engaged in the analysis of new internal factors, e.g. by emphasizing the factor of interest groups. Due to the existing relationship between industry and the development of the economy as a whole, between economic independence and political autonomy, between military might and national independence all modern states seek to have modern industry. The Chinese case may be reasoned by a proposition formulated by K. Marx that less developed countries try to employ modern technologies of the dominating state or other developed countries. It means that a few decades ago several well-developed industrial countries showed China, a poorly-developed state, its own vision. Presently, China is using its special advantage - it is able to jump over a couple of economic development stages and overcome any of the economic leaders ${ }^{16}$. In order to create an effective economy of scale and receive the needed resources of foreign exchange as well as the core capital base to finance its exports, it actively penetrates global markets. Its successful actions and the structure of lower wages allow China to be not just competitive, but also to weaken the position of economically strong countries in separate economic areas.

If one agrees with the notion that the pace of change and the time of relative diffusion make the greatest impact on the development of a new industrial state ${ }^{17}$, one should recall that the Chinese program of the four modernizations has been in progress since 1978. Its goal has been the declared strive at creating a modern and socially-focused market economy and the defence system to match the state of a superpower. At the time, there were increasingly more hardships in the world due to the increasing pace of the advantageous change and external shake-ups. When the prices of the energy resources suddenly jumped four-fold, the consumer needs changed and the capital funds of leading industrial nations seemed to be obsolete. Economic analysts and progressive political leaders started to note that backwardness has its own advantages, and it is not that easy to be among the leaders. In a situation like this market newcomers may have the upper hand by adhering to aggressive and "incorrect" tactics"

\footnotetext{
${ }^{16}$ Sen, Gautam, The Military Origins of Industrialization and International Trade Rivalry, New York: St.Martin's Press, 1984, p. 15.

${ }^{17}$ According to G. Sen, before the rise of China, for a relatively short periods of time the lion's share of the glogal industry was taken by Great Britain (after the Napoleon wars to the end of the XIX century), Germany (between 1890 and 1913), the USA (after 1890 m. until now), Japan (recognized in 1981 as the main exporter of capital) [see: Sen (note 16)].

${ }^{18}$ Rostow, W.W. Politics and the Stages of Growth, New York: Cambridge University Press, 1971, p.64.
} 


\subsection{Infrastructural Boom - a New Economic Multiplier}

The world statistics for 2008 show that the vision, which has been promoted by the industrialised states in the under-developed countries, has been perceived as a realistically achievable goal - the world's largest ever boom of investment into infrastructure of the developing countries has been infer way. According to analysts, the developing countries will witness investments of about 22 trillion USD in the next 10 years for the projects of new highways, railroads, power supply lines and telecommunication. 43 percent (about 9.3 trillion USD) of these investments will go TO China ${ }^{19}$. The same sources claim that infrastructural projects in China accounted for about 12 percent of GDP during the last five years, which means that there has been as much real value created in China in those five years as in the whole XX-th century. Although most of the theoretical economists agree that good infrastructure has always been the most important prerequisite to a country's fast economic growth, other opinions exist saying that a state's overspending for infrastructural projects is a consequence of economic growth. It is believed that China's needs for power, housing, sanitary and transportation services grow as better-off "villagers" migrate to cities.

The growing demand always provokes investment in promising areas. Goldman Sachs bank for instance has been actively promoting a model that identifies a correlation between the demand for infrastructural investment and the general level of economy, population and urbanization. He bank's specialists have calculated that if a relative proportion of the urban Chinese people increases by 1 percent, the demand for installed capacity increases by 1.8 percent. If the income per capita in China increases by 1 percent, the demand for power will increase by 0.5 percent, the number of airline passengers will increase by 1.4 percent, etc. This kind of logic evokes projections that the aggregate installed power capacity in China should be increased by 140 percent in the next decade, the number of air-travellers will increase by 3.5 times (which means a boom in the construction of new airports), and the number of mobile phone users may increase by 13 times. In other words, the development of modern China's infrastructure, which is sometimes called either the prerequisite or the consequence of the economic growth, can more correctly be called the most modern economic multiplier.

Firstly, the infrastructure investments offer huge number of jobs in the construction of new roads, railways and telecommunication facilities. Secondly, the income of the society is increased this way as well as fast consumption. Thirdly, as transportation improves, the farmers provide the cities with more raw materials from more remote areas, and the producers export more products. Finally, the growing demand for construction materials and equipment keeps their prices high and, at the same time, keeps the high price level of other consumer goods. All this will stimulate the production development in China

19 “Building BRICs of growth", The Economist, June 7"th 2008, p. 80. 
itself and increase imports of additional amounts of goods, which in its turn will decrease the surplus of Chinese current account. If China manages to remain a country with the lowest transportation costs, the country will further enjoy growing indicators of its foreign trade and economy. According the calculations of the World Bank, as investment in China's infrastructure increase by 1 percent, the country's GDP supposedly will increase by the same figure.

It is believed in the business circles that the investment in China yields good financial return. This has been confirmed by the investor surveys conducted by the US-China Business Council and the EU Chamber of Commerce. According to the surveys, 83 percent of the investors in the China's economy received the profit for 2007, which was in line with their expectations, and 23 percent of the respondents pointed out that it was the same as the average figure for their company - the profit level was the same as in other foreign subsidiaries of the company. 84 percent of the respondents pointed out that the Chinese investment was in line with the company's priority strategic goals; 46 percent were creating a platform for their exports to other Asian countries, and 28 percent - for their goods to be exported back to the US. 85 percent of the surveyed businessmen said that the income of their Chinese subsidiaries grew considerably in 2007 compared to the previous year, and 61 percent of them had no doubt that similar income will be generated by their Chinese subsidiaries between 2008 and $2010^{20}$. Thus, we should recall a fundamental assumption of the rational expectations theory - in the long-term, it is the expectation that influences the demand, which consequently determines the production. Assuming that market players formulate their future expectations by using the available information in the best possible way, which sometimes is done indirectly by following public and private expert assessments, we can understand the misgivings of the world economic development researchers about China, a regional competitor, evolving into a global one. The investment program of a massive scale that Chinese economy is ripe for may absorb the volumes of private capital, which have been considered beyond imagination so far. All this as it is projected, will stir up the stock exchange of the country, especially as far as the demand for long-term state bonds are concerned and legitimate the new changes of investment regulation.

\subsection{The New Manager of the World Finance}

China was started to be called the Financier of the World in 2008, when it was realized that the surplus of its current account increased from 1- 3 percent in the beginning of this decade to 9.5 percent and is increasing further on, and the capital account balance has been positive for a number of years and is growing further.

20 "Special Report: Strategic Economic Dialogue Aftermath", http://www.uschina.org, 07042008. 
Although the official reports of international institutions assume that business conditions in China still remain rather complicated and that a protectionist policies are pursued in certain sectors, the country's economy attract more and more foreign direct investment inflows. Fully-owned foreign capital companies, it is assumed, are the main target of the foreign direct investment (FDI). The companies of this kind accounted for 78 percent of all newly legalized investment structures in 2007. Although the total number of investment projects that were approved in China in 2007 decreased from 41,485 to 37,888 compared to the previous year, they attracted 13.8 percent more investment financing - the absolute amount accounted for 82.66 billion USD ${ }^{21}$. Thus, the investment environment reports believe that, as in previous years, China will remain one of 5 most popular directions of the world capital movement. Despite the fact that the largest share of the foreign capital went to the Chinese manufacturing industry in 2007 - over 40 billion USD, while transport, storage, post, telecommunication and other infrastructure project development employed only about 2 billion USD, it is expected that statistical data for 2008 will show significant shift towards the latter investment area.

However, there are increasingly visible indications that the wave of speculative capital that established itself in China in 2008 will be much greater than ever before in the world's economy. The present market knowledge experience becomes not sufficient enough in order to comprehend the reasons for this phenomenon and its possible consequences. Which ever way the best analysts of the world play with the funds, they are not able to explain where about 214 billion USD turned up from in the Chinese market during the five months of 2008. The country's increasing trade surplus and DFI may explain just about 30 percent of the official foreign exchange increment ${ }^{22}$. Thus, the idea becomes increasingly popular that the Chinese financial market is not different from other developing markets with their original phenomenon - "hot money". For instance, Michael Pettis of the Guanghua Business School of Beijing University believes that the amount of such funds in the Chinese economy reaches about USD 200 bill. The scientist's number is based on the assumption that many of the foreign companies overstate the declared indicators of export and DFI, and the financial capital flow to China is above the investment needs, so "it works somewhere else"23.

The statistical directories declare that that the main sources of the investment in China's economy have remained the same in the last several years - in accordance with the investment amounts, the top of the list includes Hong Kong, the British Virgin Islands, South Korea, Japan and Singapore. The data of 2007 show that the top ten investor countries that comprise about 87 percent of all investments in China lost the only EU country on the list Germany. Its portfolio decreased by 63.4 percent - the investment was taken

\footnotetext{
${ }^{21}$ Report (note 20).

22 "Hot and bothered", The Economist, June 28 ${ }^{\text {th }} 2008$, p.81.

${ }^{23}$ Ibid.
} 
over by the investors from Mauritius, West Samoa, the Cayman Islands and the USA. The situation in the Chinese market was called a phenomenon, and raised concern for the Chinese State Administration of Foreign Exchange and the State Administration of Taxation. According to their information, at least $2 / 3$ of the DFI become round-tripping when companies and private persons transfer huge amounts of money to "tax havens" and return to China in the form of $\mathrm{DFI}^{24}$. At that, they surely use the benefits increasingly offered by the Chinese government.

In 2007, new players drew the world financial analysts' attention - PRC's Sovereign Wealth Fund and the Chinese Investor Corporation (CIC). The latter acquired the Blackstone share package worth 3 billion USD and 9.9 percent of Morgan Stanley shares worth 5 billion USD. It has been announced that during 2008 , the Chinese outbound foreign direct investment will account for 37 billion USD of total outbound FDI, when respective amount was 26 billion USD in 2007, and 21.2 billion USD in 2006. Although the share of the Chinese government in the deals is not made public, it is believed to comprise about 86 percent $^{25}$.

At the time when powerful market forces strive at crossing the Chinese and other countries' borders in the form of trade, funds and foreign investment, avoid political and economic control and integrate societies of different countries, the state bureaucracy interests and state logic enjoy a special status in the arena of the Chinese economic struggle. Like Robert Heilbroner ${ }^{26}$ predicted two decades ago, the willingness will always remain in the competing states to retain and control the capital accumulation in the hands of the governments and to make it work for the goals projected by the state and for the benefits of powerful influential groups within the state; this is what takes place today in the People's Republic of China.

\subsection{Economic Nationalism - Arena of Fight for Greatness}

It was projected a quarter of a century ago that as economic leap of Asian countries can be expected when three major conditions will be met in the region. First, a strong national bureaucracy should be formed that would establish what things have to be done first, what kind of trade, investment and other commercial agreements can serve the national interests and meet the conditions that help the national economies interact with the larger world economy. Second, huge investments need to be done in science and human capital. Third, a country should embrace market laws, and the distribution of resources should be based on the price factor ${ }^{27}$. A policy favourable to industrial development is the basis for the national security and military power of any

\footnotetext{
${ }^{24}$ Report (note 20$)$.

${ }^{25}$ Ibid.

${ }^{26}$ Heilbroner, Robert L. The Nature and Logic of Capitalism, New York: W.W. Norton, 1985, p. 94-95.

${ }^{27}$ Hofheinz, Roy Jr., and Calder Kent E., The Eastasia Edge, New York: Basic Books, 1982, p. 24-28.
} 
developing state. However, economic nationalism emerges due to the market feature of accumulating wealth and creating power relationship among the market players of different strength.

There has been no consistent approach to the importance of foreign capital for the state's economy in the Chinese economy - the favourable approach and one of animosity are interchangeable. Thus, the world's business top-ten list of problems and concerns gives a very high rating to the latter aspect of China. The leaders of the Chinese economic policy openly declare that they need to make foreign capital work in the way that it promotes indigenous innovation. The "quality" parameters of the innovations are being discussed in major national political documents, e.g. in the 11-th five-year plan of the development of high-tech industries and the 2007 Guidelines for attracting foreign investment. The Chinese government tries to ensure that more financial resources would be directed to the development of new and modern technologies, that is why 2007 saw the preparation and approval of new edition of a special political document, the Catalogue Guiding Foreign Investment in Industry. The document clearly shows all the investment "places" acceptable to the Chinese government and describes the benefits expected from the country's government once a proposed business area is chosen. However, as in older editions of the document, the country's industries are divided into three categories: where the investment is promoted, where it is restricted. and where prohibited. The new edition's "restricted" category included a few additional businesses - export-processing industries and heavy or rescue intensive areas like chemical, machine and equipment as well as agricultural industries.

Nevertheless, the main concern of foreign capital managers and potential investors in China is the new Antitrust Law which, after 14 years of comparative centralism, is supposed to regulate the economy since August 1, 2008. In their presentation of and the comments on the new document, the Chinese legal experts call it "the constitution of the economy" and declare that, finally, the state centralized policy and state ownership will be substituted with the market relations ${ }^{28}$. According to the authors, the new law reflects the belief of the government of modern China that economic restructuring, which was started after Mao's death can be continued further only when the local consumers are able to use the benefits of competition - low product prices and higher quality. The government officials say that since 2006, the Anti-Unfair Competition Law, the Price Law and the Consumer Rights and Interest Protection Law have become similar to the laws in many countries, which are "toothless", non-transparent "toys" in the hands of the bureaucracy. They say that the dominant companies of the country impose their price policies on the state not only in strategic industries - energy, transport and metallurgy - but also in providing food products to the country, e.g. in setting the prices for rice, grain and noodles to the consumers and processors alike.

In the context of these and similar assessments, many of the provisions in

28 "Busting trust", The Economist, July 19 ${ }^{\text {th }} 2008$, p. 67 
the new Antitrust Law sound rather cynical. Firstly, though the validation date of the Law was postponed several times, there were no by-laws in place on the day of its validity to explain the implementation circumstances of separate provisions. Analysts are joking that the "holes" in the Law are as big that China itself ${ }^{29}$. For instance, the Law establishes sanctions for the monopolies partly owned by the state only when their business presents a threat to economic or national security of the country, but most of the large Chinese companies have always been and will remain to be state-owned. Secondly, on the basis of the EU practices, the Chinese government has given the right by this Law to special controlling institutions to evaluate and bless the companies' applications for mergers or acquisitions if it happens on the Chinese territory or has an impact on other local companies. The businessmen will have to wait for the "blessing" from 30 to 180 days; the main criteria for a favourable decision - "the progress of technology" or "national economic development". It is obvious that the new Law is directed solely at foreign companies that will incur a lot of additional costs if they try to expand their business influence in agreement with the Chinese business owners. Thirdly, the new Law does not give the description of the criteria that would determine that a company is "dominant; that is the reason why in separate cases there will be inevitable conflicts about intellectual property rights. E.g., in the Chinese sectors of software and pharmacy, as it was declared before, several foreign companies are dominant. Direct implementation of the new Law provides for the possibility of restricting their business, e.g. by revoking or restricting their licenses for the production of particular items that, as a rule, is usually related to large initial costs of $R \& D$, which are taken into the product prices for long-term business. Fourthly, the struggle for the institutional rights to control the implementation of the new Law has uncovered an essential problem of the Chinese economy - the inert character of the national bureaucracy and its strive to exercise priority over regional bureaucrats who were empowered until recently to regulate the business of local companies including foreign ones. At the day of the Law coming into force it was not announced, which institutions would control its implementation in the country. The world press projects that the "grand prize" will be given to three institutions that represent certain groups of trade interests and are supported by all means available in the state-controlled economy.

These facts provoke an assumption that the Chinese national bureaucracy that is under immense influence of defensive economic nationalism and is looking for disproportionate economic benefits for itself may lose the basic stimulus of economic growth breakthrough - the foreign investment. Especially that more and more facts emerge to prove that the Chinese economy is much too sophisticated and that the country lacks its own ideas, innovations and

${ }^{29}$ Ibid. 
technology - everything is owed from bottom to top ${ }^{30}$ without creating added value. Up till now the country has been competitive not by its innovations and quality but solely by its cheap labour force: e.g. if the cost of an assembled TV set was on the average 73 USD in China in 2003, it was double higher in Malaysia and four-fold in the USA. It shows that the time China needs for the transition from net importer of technology-intensive goods to net exporter is likely to take many decades.

\section{Society Where a Million is Not a Significant Figure}

At the background of modern China, two approaches take shape with regard to the perspectives of state power and economic growth. The first one is based on the analysis of the variations of traditional factors, the GDP and foreign investment. The multitude of opinions and projections is formed by international agencies, academic institutions, think-tanks, publications of various deviations and Internet sites. Although it is always reminded that the Chinese press and information is restricted by the government, the publicly available facts include references to the publications in Chinese by internal experts, those from Hong Kong and Taiwan. Another approach is based on the analysis of rarely publicized Chinese memorandums and internal policy documents. Thus, a new wave of assessments and debates is emerging with the focus on the Chinese foreign policy and the internal problems of social divide. More often than not one can hear the idea of the breadth and depth of the Chinese officials and their foreign policy, and the rising importance of the Maoist and Marxist heritage within it ${ }^{31}$. MIT professor Yasheng Huang in his study draws attention to the price that the Chinese people are paying for the opportunity to be called a phenomenon; he says that one has to look at China as a dual state ${ }^{32}$. One side of it is a part of the population that lives an urbanized and state-controlled life; another is vibrant, entrepreneurial and rural that "finances" the urban growth by poor living quality and increasing taxes. According to Yasheng Huang, the social divide and poverty in the Chinese provinces do not show any signs of decline. It is supported by the fact that between 2000 and 2005, when schools and hospitals were closed down on a massive scale in rural areas, the number of illiterate Chinese increased by 30 million.

There is no agreement still on the academic level about the reason for

\footnotetext{
30 "A special report on technology in India and China", The Economist, November 10 th 2007, p. 7.

31 "China Analysis: 19", European Council on Foreign Relations, Asia Centre, Sciences Po, http://www. centreasia.org., 14082008.

${ }^{32}$ Huang, Yasheng, Capitalism with Chinese Characteristics: Entrepreneurship and the State, Cambridge University Press, 2008, 368 pages.
} 
the poverty of separate states or social groups. All known theories are attempted to bring under three groups: the first one includes assumptions that the poor simply work poorly, and it is only effective economy that is able to free them from poverty; the second one - that the poor do not have the power and thus are being exploited so they should attain the state governing power; the third one - that they have been put into a vicious circle of poverty that can be broken only from the outside ${ }^{33}$. However, in our time of modern direct communication it is not difficult for the people who live in most remote areas on Earth to find out about the wealth and benefits of others provided by material progress, and poverty is no more something accepted as a natural state. The Chinese situation shows that the hopes and expectations of millions of people exceed the possibilities of the society to make these dreams come true, so one can say that they are just the regularity of human behaviour ${ }^{34}$ and cannot be called rational. However, the Law of large numbers becomes very relevant when we speak about the problems of social divide and possible power of the wave of discontent.

On the other hand, a part of the Chinese political elite ideology has always been the will to strive in order to demonstrate to the rest of the world the modernity and financial prosperity of the society and to indirectly ignore the problems of the social divide. The fact of the Olympic Games in the first half of 2008 was mentioned by comparing it to the event of 1936 when the Olympic Games took place in Berlin under the Nazis. However, the publications that voiced the opinions of the Chinese officials and separate citizens repeatedly stated that such a comparison was just another petulant effort by Western foes to thwart China's inexorable rise ${ }^{35}$.

Common travellers who are fascinated by centennial Chinese religious, cultural and medical traditions notice simpler and more realistic "Olympic" changes ${ }^{36}$. Millions of people have turned to be "somewhere out there" having no ID, no education and social guarantees, who come from poor provinces and villages overtaken by redundancy in unfertile regions. All of them are the result of the crazy family planning policy that was started back in $1949^{37}$. They were exchanged for 500 thousand smiling service-minded "volunteers" mobilized by the state to take care of the guests during the Games.

It seems like the dispersed human mass that by unofficial estimation reaches 200 million, does not fit into the Chinese government's plan of creating a "harmonious society", which it is promised, will be implemented by 2020 .

\footnotetext{
${ }^{33}$ It is assumed that the first to offer this kind of classification of the poverty reasons was Ragnar Nurkse (see.: R.Gilpin, Tarptautiniu santykiu politine ekonomija, V.: “Algarvè”, 1998, p. 487).

${ }^{34}$ Hirschman, Albert, Essays in Trespassing: Economics to Politics and Beyond, New York: Cambridge University Press, 1981, p. 62.

35 "China's dash for freedom", The Economist, August 2 $2^{\text {nd }}, 2008$, p.11.

${ }^{36}$ Dikčius R., "Geltoni raguočiai”, Istorijos, 2008 m. rugpjūtis, Nr. 8, p.80.

${ }^{37}$ For instance, Mao Zedong declared the slogan "The more numerous we are, the more powerful we are", and later "a single child policy" was introduced that forced village women to give birth to children and raise them illegally.
} 
The plan is for millions of other Chinese people - for those who, by applying double standards, call the achievements of the liberal Western democracies a sham, accuse businessmen of industrial nations of transferring polluting industrial processes to their country who presently attempt to enjoy the rights of the "new Chinese" for the pleasure of using private cars and freedom of movement. The plans of creation a harmonious society do not include of course, the incidents of either nationalistic nature or the ones provoked by economic reasons. The latest official data include only 9 months of 2006 and show that the number of protests and incidents decreased by 22 percent in comparison to the previous years. However, the number of various protests and incidents in China was calculated at over 74 thousand in 2004, when their number was only 10 thousand back in $1994^{38}$. Anti-Western nationalistic outbursts that involve millions of Chinese within the country and abroad become in a way useful both for the government that is able to demonstrate to the world that it is capable of managing the masses and for the national bureaucracy which is notorious for high degree of corruption and a special system of permits-bans.

The Chinese government has been able to maintain its grip on power for three decades by painting a vision of economic prosperity to the people. Millions of Chinese are presently enjoying the way of life created by favourable circumstances that their fathers could not even dream about. But the minds of the "new Chinese" need new inspirations, and the government has created a new strategy by promising that their country will get back the "fair" place in the centre of the world economy. Unfortunately, as history shows, any escalation of nationalism very often turns its back on national governments.

\section{Concluding Remarks}

The modern PRC's economic, political and cultural-civilization influence denies an essential assumption of political economy that conflicts are inevitable in the world of national states and political borders when a rising state tries to overcome existing barriers. The Chinese people actively show to the world that they strive at recreating the fairness principle in a hierarchic society and regain their former regional and world power; they consistently realize the far-reaching vision through their national and regional bureaucracy. The investment program of immense scope that the Chinese economy is ready for, together with the surplus of the financial capital in the world that is looking, as a rule, for places where it can reach the largest marginal profitability, is in line with the Chinese rational expectations. Having understood the opportunities of the most modern economic multiplier - the infrastructural development - the

38 "A lot to be angry about", The Economist, May 3 ${ }^{\text {rd }}, 2008$, p. 61. 
Chinese national bureaucracy will be able to use further the benefits of foreign investment directing it by administrative and political decisions to the areas that best meet their own interests. China's government will be able to rule the minds and produce of over a billion-strong nation effectively manipulating by the power of the image tools explained by the cognitive dissonance. Thus, it is probable that China will succeed in using a big advantage of an "underdeveloped country" - an opportunity to jump over certain economic development stages and this way surpass any industrial leader.

This assumption is provoked by the analysis of the sources and possible consequences of the world financial crisis of 2008: it becomes obvious that huge debts and bank nationalization can be expected, a long-term recession in the USA and European countries as these countries have been using much more than they produced for a quarter of a century, and they have not been able to manage their deficit problems. However, the communist China has been working profitably; it saved and accumulated wealth. The present financial turmoil opens an opportunity for China to invest the accumulated funds successfully in Western markets - to transfer its dollar reserves, for instance, to the USA assets and this way minimize its losses from the shrinking world production, to change gradually the balance of the world power and eventually take over the world leadership. However, the projections should not ignore an important word in economy - "if"... for instance, exported goods will make an influence on inflation alterations throughout the world if internal prices and wages in China grow considerably slower than in the rest of the world due to the means of administrative control. A more vigorous increase of local demand in 2008 will continue to influence China's BVP growth if the income distribution, which is still rather vague, does not aggravate the country's social tension that is quite visible. China will retain foreign investment, the main stimulant of economic growth, only if the strive of the national bureaucracy to have priority over regional bureaucrats and serve the powerful influence groups, which has been demonstrated by the means of rising economic nationalism, will visibly diminish.

A deeper analysis of facts and figures undoubtedly would help formulate even more assumptions and hypotheses that may cast doubts about the rising might of China's economy. For example, the population growth - if China's economy is at the same level as the USA's by certain parameters, the created income per capita will reach only $1 / 4$ to $1 / 3$ of the American level. Secondly, Western European and American economies have already been "diseased", and the spreading infection unavoidably would decrease China's economic indicators. Thirdly, a serious approaching problem is the incompatibility of the declared socialism in the Chinese society and market relations, which is talked about even by the country's leadership ${ }^{39}$. China will

${ }^{39}$ Hu Jintao, "Building harmonious socialist society", Speech at the Special Discussion Class for Principal Leading Cadres, Xinhua, 30/06/2005. 
continue to face a growing problem of energy security due to declining oil resources on Chinese territory, fast growth of industry, urban development, population and speed of economic expansion. The possible future disruptions in the supply of raw materials and the rapid increase in resource prices would not only have serious impact on China's economy but also fuel social issues and provoke disturbances that might weaken the influence of the Communist Party.

September, 2008 